\title{
Immunovirological parameters and cytokines in HIV infection
}

\author{
Karen Ingrid Tasca ${ }^{[1]}$, Sueli Aparecida Calvi ${ }^{[1]}$ and Lenice do Rosário de Souza ${ }^{[1]}$
}

[1]. Departamento de Doenças Tropicais, Faculdade de Medicina de Botucatu, Universidade Estadual Paulista, Botucatu, SP.

\section{ABSTRACT}

Although modern combined antiretroviral therapies (CART) result in lower morbidity and mortality and a visible improvement of clinical and laboratory parameters in HIV-infected, it is known that their long-term use contributes to appearance of the many events unrelated to AIDS such as cardiovascular diseases, cancer and osteoporosis, comorbidities which have been proposed as some of the most important that deprive the majority of infected to present an even better prognosis. This is because even with a decrease in inflammation and immune activation after drug intervention to the patient, these parameters remain higher than those shown by healthy individuals and the imbalance of cytokine profiles also persists. Therefore, evaluations of other biomarkers in clinical practice are needed to complement the exams already carried out routinely and allow more effective monitoring of HIV patients. This review aims to investigate the role of cytokines as potential markers showing studies on their behavior in various stages of HIV infection, with or without cART.

Keywords: Cytokines. HIV/AIDS. Antiretroviral therapy. Clinical stages of infection.

\section{GENERAL CHARACTERISTICS OF HIV INFECTION}

The principal damage caused by the human immunodeficiency virus (HIV) is the progressive deterioration of the cellular immune system that leads to severe immunodepression and renders the individual more susceptible to opportunistic diseases or certain types of neoplasms ${ }^{1}$. Several cell types are susceptible to the virus, such T lymphocytes and some antigen presenting cells (APC) due the presence of cluster of differentiation $4(\mathrm{CD} 4+)$ on its surface, which allows the entry of the virus into host cell2.

The infection is characterized by an acute or primary phase, in which a higher viremia peak occurs ${ }^{3}$ and a chronic phase, established firstly by the control of infection or what is denominated clinical latency or asymptomatic phase, followed by a symptomatic phase in which intense depletion of CD4+ T lymphocytes and a continual increase of plasmatic ribonucleic acid-human immunodeficiency virus (RNAHIV) viral load (VL) are observed until the moment that opportunistic infections appear, characterizing the acquired immunodeficiency syndrome (AIDS), the aforementioned disease ${ }^{4}$.

In untreated individuals the average time of development of AIDS is 10 years in typical progressores (TyP), although it can develop in 3 to 6 months in some rapid progressors ${ }^{5}$. A minority of individuals infected by HIV, denominated long term non-progressors (LTNP) remain healthy for more than 10 years without clinical evidence of disease progression ${ }^{6,7}$ in the absence of combined antiretroviral therapy (cART). These cases, represented by approximately $5 \%$ to $15 \%$ of those infected ${ }^{8}$ are characterized by stability or increase in $\mathrm{CD} 4+\mathrm{T}$ count and strong response of cytotoxic T lymphocytes (CTL) against HIV, different to what occurs in TyP9.

\footnotetext{
Address to: Msc. Karen Tasca. Depto de Doenças Tropicais/FMB/UNESP. Rua Tulipas 62, Jardim das Rosas, 13309-504 Itu, SP, Brasil.

Phone: 55 11 9-9739-9405

e-mail: karenitasca@hotmail.com

Received in 02/02/2012

Accepted in 19/09/2012
}

The evolution in the therapeutic efficacy occurred principally after the introduction of a highly active CART that promotes the $V L$ reduction to undetectable levels in peripheral blood ${ }^{10}$. Even with the emergence of this therapy, the virus persists in organism reservoirs, mainly integrated into the genome of non-activated T lymphocytes ${ }^{11}$ and other latent cells ${ }^{12,13}$, which leads to the unviability of discontinuing the treatment ${ }^{14}$. Furthermore, the emergence and velocity in the appearance of resistant strains to different drugs combination available on the market constitute a limiting factor in controlling the infection ${ }^{15-17}$.

Nevertheless, the great research challenge is to discover possible targets that effectively disrupt the HIV cycle without causing damage to the normal cell, since several studies have demonstrated great impairment in the organism of patients due to cytotoxicity caused by these drugs ${ }^{18,19}$. For this reason the investigation of immunologybased therapies that allow the host to maintain control of the infection should be encouraged ${ }^{20}$. In this sense cytokines arise as a one of the principal targets for an immunomodulatory intervention ${ }^{21}$ or, according to Imami et al. ${ }^{22}$, the determination of the cytokine profile in patients HIV seropositive, when properly designed could complement the data from VL and CD4+ T count in the analysis of the disease status, thus aiding in the decision among possible therapeutic interventions.

Some studies suggest that early initiation of CART in HIV infection can reduce the viral reservoir and thus diminish its transmission ${ }^{23,24}$. However, early intervention has not shown substantial long-term clinical benefits ${ }^{25}$. Given the evidence of longer survival, temporal studies on the causes of death by AIDS, in the pre- and post-cART periods have evidenced that special attention must be given to the prevention of chronic diseases, which arise from the prolonged use of cART such as weight gain, metabolic syndrome, lipodystrophy, insulin resistance, diabetes and obesity, which are risk factors for a series of new comorbidities ${ }^{26}$. Conclusions of a study by Cozzi-Lepri et al. ${ }^{27}$ call attention to the significant association between patients that developed non-AIDS comorbidities and the presence of soluble inflammatory markers including interleukin (IL)-6, high sensitivity C-reactive protein and D-dimer ${ }^{28}$, indices that are presented elevated even after years of effective treatment. Although the administration 
of CART is able to reduce these biomarkers levels, it is necessary to observe failures in the normalization of these inflammatory parameters despite prolonged treatment, to understand the longterm prognosis ${ }^{29}$.

\section{CONSTANT AND INTENSE INFLAMMATORY STATUS IN BOTH INITIAL AND LATE INFECTION WITHOUT CART}

According to Keating et al..$^{30}$ in 2012, it is known that HIV causes a profound disruption in the cytokine network from the earliest points of HIV infection, shortly after first detection of systemic virus. Therefore, in the complex cytokine network the balance between viral suppressors, such as type I interferons (IFN- $\alpha$, IFN- $\beta$ and IL-10 and the viral inductors, including IL-6, IL-15, IL-1 $\beta$ and tumoral necrosis factor (TNF- $\alpha$ ) contribute to establishing in each individual, an equilibrium point of viral replication that is determinant for the prognosis of AIDS ${ }^{31}$. For example, an in vitro study revealed that several cytokines with inductor effects of viral replication can be mediated, as in the case of TNF- $\alpha$, by activating the binding of kappa B nuclear transcription factor (NF-KB) to the LTR region (long terminal repeat) of the virus ${ }^{32}$. For this reason the augmented production of TNF- $\alpha$ was verified in HIV patients with and without treatment in comparison to those seronegative, but this difference was greater in treatment naïve patients ${ }^{33}$, probably due the inadequate viral suppression. The TNF- $\alpha$ is a potential inflammatory cytokine, such IL-1 $\beta$ and IL- 6 and the first and last exhibit synergistic effects ${ }^{34}$. Relative to this, it is clear that the rise in serum levels of pro-inflammatory and inflammatory cytokines contributes to viral replication and many manifestations of immunodeficiency ${ }^{35}$. Others cytokine production can increase viral replication, due the activation role in HIV infected cells, including IL-2, IL-4 and interferon type II (IFN- $\gamma$ ) which, primarly, are required in the support to expansion of antiviral T cells and antibody responses ${ }^{30}$.

During the acute phase of HIV-1 infection, was showed ${ }^{36}$ that elevated plasma levels of inflammatory cytokines are associated with viremia peaks and can even estimate the time at which the CD4+ T count will drop below 350 cells $/ \mathrm{mm}^{3}$. Thus it would be important low levels of these cytokine in this critical phase. Some authors ${ }^{20}$ reported that in this initial phase occurs an increase of cells producing IFN- $\gamma$, a potent antiviral cytokine, as well as the increase on this cytokine in serum, while the frequency of IL-4 producing cells and the amount of the cytokine secreted are decreased. This cytokine displays both stimulatory and inhibitory effects on HIV replication and leads to Th2 profile. Beyond IFN- $\gamma$, Noris et al. ${ }^{37}$ demonstrated significant initial increases of TNF- $\alpha$ and IL-10, while Rychert et al. ${ }^{38}$ evaluated the correlation of plasma gp120 with change in the cytokine profile and found that plasma gp120 levels were related to the increase of TNF- $\alpha$, IL-10 and IL- 6 . These last studies reinforce the importance of low viremia peak for the infection being directed to a better profile. In addition, a review by Katsikis et al..$^{39}$ showed the evidence that viral set-point can be manipulated by cytokine interventions during acute infection by the simian immunodeficiency virus (SIV) and HIV and they raised the question: would be possible use of cytokines through immunotherapeutics and potentially vaccines to alter viral set-point during acute HIV infection? It is an interesting question that deserves to be studied, once the cytokines can both change and/or be changed by high viremia.

In addition to the initial of the infection, in a cohort study of women at high risk for HIV acquisition, Roberts et al. ${ }^{36}$ observed that
IL-12 and IFN- $\gamma$ levels were significantly associated with lower VL, but IL-15 and IL-7 with higher VL, and the latter also with lower CD4+ count. These authors demonstrated significant rises in IL-1, IL-2 and IL-7 at approximately six weeks after the infection ${ }^{36}$. Interleukin-12, despite be consider a pro-inflammatory cytokine, plays a central role in host resistance in models of infection with many pathogens that cause opportunistic infection in HIV seropositives ${ }^{39}$ and the common gamma chain cytokines, IL-2, IL-7, IL-15, and IL-21 appear to be pro-viral but they are essential to maintain the proliferation, function and T cells homeostasis ${ }^{20,30,40}$ already during the primary HIV infection.

In reference to the onset of infection a retrospective study ${ }^{41}$ with plasma samples from frequent donors of blood, before and after the acquisition of HIV, demonstrated an increase in multiple cytokines and chemokines during higher viremia, which is the moment when the immune activation is elevated and the clinical symptoms begin to appear. Thus, the serum concentration of cytokines was analyzed at the beginning of the infection, even before serological positivity and revealed elevated levels of IFN- $\gamma$ and IL-15 before the viremia peak. In acute HIV infection the patients presented high serum levels of IL-18, IL-6, IL-10, followed by the later appearance of high levels of IL-1 $\beta$, IL-2, IL-7 and granulocyte-macrophage colony stimulator factor $(\mathrm{GM}-\mathrm{CSF})^{41}$. In another work about SIV infection, the increase of IL-15 production is associated with higher susceptibility of memory CD4+ $\mathrm{T}_{\text {cells }}{ }^{42}$. However, Wren et al. ${ }^{43}$ recently has investigated the effect of exogenous cytokines on a small number of effectors natural killer (NK) cells in naïve patients and observed that IL-10 and IL-15 enhanced NK cell functionality and the anti-HIV NK cell activity, suggesting that these cytokines may be potential resources for prophylactic and/or therapeutic interventions.

Regarding the advanced phase of infection by HIV-1, Clerici \& Shearer ${ }^{44}$ showed that the cytokines can be markers of progression toward AIDS upon indicating decrease of IL-2 and IFN- $\gamma$ and concomitant increases of IL-4 and IL-10 which are associated with a decline in an antigen-specific immune response, resulting in opportunistic infections. This inversion of the cytokine profile from type 1 to 2 would have implications in the increased lymphocytic susceptibility to apoptosis ${ }^{45}$ and in decreasing of cytokines produced by $\mathrm{CD} 8+\mathrm{T}$ cells $\mathrm{s}^{57}$. A study by Sousa et al. ${ }^{20}$ detected significant decrease in the proportion of IL-2-producing CD4+ T cells too, a finding not observed in infection by HIV-2, which presented preservation of these cells throughout the natural history of the disease. In this manner, the contribution of the slower depletion of CD4+ T can be inferred in HIV-2 infection, thus highlighting its crucial role as a proliferative factor and protector of cell death by apoptosis ${ }^{20}$. Therefore, to study the dynamic of HIV infection it is necessary to consider many host and virus aspects, including the fact that intense increase in CD4+ T cell count could augment the viral targets.

It is known that in the chronicity of HIV infection, some parameters can contribute to clinical worsening. According to Estes at al. ${ }^{46}$, the exhaustion of the T cell supply occurs and could be due to direct or indirect killing by the virus, immunologic senescence and/or the architectural destruction of lymphoid organs from fibrosis induced by cytokines like TGF- $\beta$, that may interfere with APCs and T cells interactions and access to homeostatic cytokines. Huang et al. ${ }^{47}$ observed that circulating myeloid dendritic cells (mDCs) from elite controllers display increased antigen-presenting properties and release 
less inflammatory cytokines with regard to HIV-1-infected progressores. TNF- $\alpha$ levels were significantly increased in both the TyP and rapid progression groups compared with the LTNP group in a study release in naïve patients from Africa ${ }^{48}$. Differently from typical progressors, those patients that can naturally controlled the infection are able to maintain highly functional HIV-specific CD8+ T cells and the author highlighted that the quality from these cells is more important than quantity of them to a slower disease progression ${ }^{49}$. Another difference between TyP and LTNP was documented by Li et al. ${ }^{50}$ in chinese CART naïve. In vitro, the activation levels of CD4+ T cells on first group was higher than that presented in second group, and it was direct correlated with VL and indirectly correlated with T CD4+ counts. In the same study, the expression of Th1 cytokines and the frequency of Th1 cells were lower in TyP than the other group ${ }^{50}$, showing that the LTNPs maintain the control of infection progression due the less activation and Th1 cells conservation. It is therefore important that the immune system cells preserve the specificity and polyfunctionality and be able to balance the cytokines production to provide a favorable environment for viral clearance.

\section{PERSISTENT INFLAMMATORY STATUS AFTER CART INITIATE}

According to many authors such Hunt et al. ${ }^{28}$, French et al. ${ }^{51}$, Nixon et al. ${ }^{52}$ and Kamat et al. ${ }^{54}$ persistent chronic inflammation and immune activation are factors potentially determinant of morbidity and mortality not associated with AIDS, even during effective CART. Thus, it is necessary that these parameters be minimized to augment the patient survival. In this manner the direct or indirect dysregulation in the cytokine network produced due the HIV infection have important consequences from an immunological and clinical perspective 20,30. $^{2}$.

When analyzing studies with cARV and cytokines, Gay et al. ${ }^{54}$ found minimal effects from medications on the levels of cytokines and chemokines after 16 to 24 weeks of treatment. Some authors did not observe an influence of CARV on circulating levels of IL-6 and reactive protein $C^{55,56}$ while others ${ }^{33,57}$ associated the decrease of IL-1 $\beta$, IL- 6 and TNF- $\alpha$ after initiating CART. Sachdeva et al..$^{58}$ in 2010, found similar results in serum levels of IL-1 $\beta$, IL-6, TNF- $\alpha$, IFN- $\gamma$ and IL-12, which decreased after 6 months of CART, but some of these values were still higher than those of control individuals. Still, in a study by Haissman et al. ${ }^{33}, 4$ months after cART initiation there was a statistically significant reduction, mainly to the TNF- $\alpha$, IL-1ra and IL- 6 in individuals with elevated CD4+ T, and these values were similar to those found in the group not infected by HIV. It is noted that the results of cART interference in serum cytokine level are conflicting. Probably this divergence of data in cytokines studies can be attributed to the various factors responsible for not restore a complete immune response despite CART, as late infection stage to initiation of therapy ${ }^{54}$, old age of onset therapeutic ${ }^{40}$, low T CD4+ nadir ${ }^{59}$, residual viremia results from cellular reservoirs ${ }^{12,13}$, slow time to viremia became undetectable and poor therapeutic adherence.

It was demonstrated by Haissman et al..$^{33}$ that the progression of the disease exerts an effect on the levels of TNF- $\alpha$, IL-6, IL-1ra and IL-8, which were significantly higher in the patient group with CD4+ T counts lower than 200 cells per $\mathrm{mm}^{3}$. In multivariate analysis adjusted for sex and age, high VL levels predicted high levels of TNF- $\alpha$, IL-1 receptor antagonist (IL-1ra) and IL-8 and when were utilized univariate analysis, the pro-inflammatory cytokines were positively correlated with VL and, TNF- $\alpha$, IL-8, IL- 6 e IL-1ra were negatively correlated with the CD4+ T count, with the exception of IL-1033. The latter finding did not concur with a study by Sachdeva et al. ${ }^{58}$, which reported a negative correlation between CD4+ T and IL-10, both pre- and 6 months after CART, in addition to a positive correlation with IL-2 measured prior to cART. By observing only the behavior of cytokines in the presence of cART at 6 months, the last authors ${ }^{58}$ found no difference between IL-10 levels in the treated group which presented variable responses to ARV. In contrast, Resino et al. ${ }^{60}$ observed in children a greater IL-10 production in the treated group when compared to the subjects not treated with CARV, results contrary even to those found by other authors in adults ${ }^{33,57}$, who observed a decrease of this cytokine upon initiation of CART. It is important to establish the role of IL-10 in the infection, given that some studies indicate the existence of a relationship between the high production of IL-10 and slower disease progression ${ }^{61,62}$ or your importance to control the inflammation and maybe, leading to an effectiveness enhance of antiretroviral treatment over time ${ }^{13}$.

An analysis of the cytokine profile at the peak moment of $V L$ in the primary infection and another peak, after the interruption of treatment, showed significantly higher levels of IFN- $\gamma$, TNF- $\alpha$ and $\mathrm{IL}-10$ in the primary infection ${ }^{63}$. The analysis of Cozzi-Lepri et al. ${ }^{27}$ in 2011 also demonstrated a high correlation between VL increase, following treatment interruption, versus a decline of CD4+ T and increases in the production of IL-6, TNF- $\alpha$ and IL-10 by macrophages and/or monocytes. This suggests that the effect of HIV replication in these cells can constitute a critical pathway of HIV induction mediated by immune activation and inflammation, as well as a consequent immunological deficiency ${ }^{27,64}$. Nevertheless, under drug compliance and a good response to therapy, studies have shown that the impact of cART in immune reconstitution is closely related to the reduction of immunological activation due to a decline in $V L^{65}$.

Still along the same lines, under the medication influence on the cytokine profiles, Meira et al. ${ }^{66}$ observed that the IL-2 level in peripheral blood mononuclear cells (PBMC) of individuals infected by HIV-1 treated with ARV remained low even after years of therapy, and that the average of IFN- $\gamma$ was higher than in control individuals, with Th0 being the dominant profile in these patients. Other authors ${ }^{58,67}$ observed an unbalance between Th1 and Th2, with the involvement of Th2-profile cytokines in late stages of HIV infection, in which reverse dysregulation of cytokines occurred in patients with CART and the Th1 profile becomes highlight. On the other hand, this condition is only partially reversed and after years of therapy it is lost again, which leads to faster progress to AIDS. Whence, the type 1 cytokines were associated with protection against infection and constituted the objective in vaccination strategies ${ }^{68}$ or therapeutic intervention with immunomodulators ${ }^{21}$.

In relation to IL-18, a pro-inflammatory cytokine that induces IFN- $\gamma$ production in T cells and enhances NK cytotoxic activity ${ }^{69,70}$, high levels of this cytokine have been related to the symptomatic condition of individuals in comparison to asymptomatic ones and controls and which could also be to disease progression, regardless of CARV ${ }^{69}$. Treated patients presented lower levels of IL-18 than no treated, increased values have been found in late stages and its plasma levels were directly correlated with $\mathrm{VL}$, constituting a really good marker for disease progression ${ }^{69,70}$. 


\section{TH17: PROMOTION OF HOMEOSTASIS OR INFLAMMATORY STATUS?}

As seen previously, infection by HIV-1 is characterized by chronic immune activation and is associated with the increase of pro-inflammatory cytokines ${ }^{30}$. This chronic activation of CD8+ T and CD4+ T leads to clonal exhaustion of pools of memory $T$ cells and probably increases the number of target cells for the viral infection thus increasing viremia ${ }^{71,72}$. There are still other factors that contribute to a strong and intense immune activation in individuals seropositive for HIV, for example, the imbalance of Th17 type cells that are currently receiving attention in studies on HIV infection. This subtype produces not only IL-17 but also TNF- $\alpha$, IL-1, IL-2, IL-21 and IL-22 ${ }^{73,37}$. In turn, IL-17 is secreted by several cell types especially CD4+ T cells in immune activation ${ }^{75-77}$, besides $C D 8+T$, eosinophils, neutrophils ${ }^{78,79}$ and more recently by invariant NK cells ${ }^{80,81}$. It is possible that a specific extenuation of the Th17 profile would be accompanied by deficiency of IL-21, IL-23 and TGF- $\beta$, cytokines that promote this profile ${ }^{82,83}$.

Their role of IL-17 has been particularly linked to inflammatory conditions and autoimmunity ${ }^{84}$; when there is stimulus in cells by IL-17, occurs a second wave of different proinflammatory cytokines/ chemokines and of GM-GSF, leading to neutrophil recruitment ${ }^{74}$. Another pathogenic effect is that IL-17 inhibits virus-induced cell apoptosis; this protection of virus-infected cells serves as a powerful means for viral evasion of the immune system ${ }^{85}$. The inhibition of apoptosis prolongs the life of infected cells on the one hand, and desensitizes killing by cytotoxic T cells on the other, resulting in enhanced viral replication and persistence ${ }^{85}$. Studies ${ }^{86,87}$ found that, by interfering with CTL function too, IL-17 blocks vigorous and efficient antiviral immunity thereby permitting sustained viral infection. Although the protective roles of Th1 and its main cytokine, IFN- $\gamma$ have been previously cited but the roles of Th17 and IL-17 in viral infection, inducing or not inflammatory diseases, remain uncertain ${ }^{86,87}$. However, despite these harmful roles of IL-17, this cytokine and especially Th17 generally, also exert beneficial effects in HIV infection, as shown below.

The high susceptibility of Th17 cells to HIV, due to the large tropism of the virus in response to CCR5 chemokine receptor, is reflected in the depletion of this profile, in both the PBMC and gut-associated lymphoid tissue (GALT) of seropositive patients ${ }^{88,89}$. However, Th17 cells were found preserved in LTNP individuals ${ }^{90}$. Similar results were found in studies ${ }^{89,91}$ to SIV infection, when the non-human primate with progressive infection were compared to those with non-pathogenic infection and, the last group presented good control of virus replication and showed the capacity to maintain a normal level of Th17 cells in blood and intestinal mucosa ${ }^{89,91}$. In a recent study by Salgado et al. ${ }^{92}$, it was verified that the LTNP individuals presented more Th17 cells along with less microbial translocation, lower immune activation and slower disease progression when compared with TyP. Thus, several authors ${ }^{89,91,93,94}$ reported that in HIV infection, there is an association between scarce Th17 response with alterations in the balance of this profile with the consequent development of AIDS $89,91,93,95$.

It is important to remember that the GALT has been extensively studied in HIV/SIV infection because it harbors almost a majority of all lymphocytes in the body ${ }^{96}$ and that the intense depletion of Th17 in this system promotes alterations in the structure and function of this mucosa $a^{97,98}$ which culminates with the rupture of the epithelial barrier ${ }^{99}$ due the loss of local integrity and intense apoptosis of epithelial cells.
Thus, an increase in the secretion of pro-inflammatory cytokines occurs which facilitates the mucosal tissue damage ${ }^{100,101}$, alterations in bacterial flora and the microbial translocation of gut lumen to peripheral blood ${ }^{102}$. In this manner, the increase of immune activation and general inflammation are induce $d^{102,103}$ and, consequently, the disease progression ${ }^{104}$. Therefore, this fact suggests that Th17 cells can improve host defense through their capacity to maintain local homeostasis, prevent microbial translocation and systemic immune activation as well as elevate the potential to protect against opportunistic infections $\mathbf{s}^{74,89,91,93,105}$.

Rather than imagined, in HIV seropositives with and without CART, Hed et al. ${ }^{88}$ demonstrated that the portion of IL-17+ T cells was reduced in those under CART independently of the VL value, which did not occur in naïve HIV-infected or in HIV-uninfected. But, among patients that had used CART for a prolonged period of at least 5 years, Maçal et al. ${ }^{94}$ demonstrated that some of them were able to reconstitute this Th17 population and increase CD4+ T cells in the blood to normal levels. Nevertheless, it is still unclear whether CART produces an increase of Th17 despite the elevation in the CD4+ T cell count.

One possible explanation for the findings of pro-inflammatory IL-17 increase and protector Th17 decrease is that, higher doses of IL-17 are not always related to greater presence of the Th17 lineage and it is conceivable that the constant immune activation or exhaustion suppresses the effecter functions of Th1 $7^{88}$. Furthermore, Th17 cytokines other than IL-17 may be able to modulate protective antiviral T cell responses ${ }^{86,87}$. In fact, in HIV infection, it is seems that the presence of Th17 is important to homeostasis but these cells need to present a normal and regulate IL-17 secretion.

\section{LAST CONSIDERATIONS}

Finally, the fact is that ARV induces not only quantitative but also qualitative alterations in the cytokine profile of persons that are living with HIV warrants attention ${ }^{60}$. In this manner it can be inferred that, for individuals that have access to CARV, the needs are not only the discovery of new medicaments and the implementation of programs that are intend to encourage and stimulate the medication adherence to patients ${ }^{106}$ but also the search for new interventions aimed at persistently decreasing immune activation and chronic inflammation ${ }^{107,108}$. After all, studies suggest that the attenuation of inflammation induced principally by products from microbial translocation can promote the improvement of clinical results and, it take together with adequate viral suppression, the AIDS progression and mortality can be reduced ${ }^{109}$. These findings can supply a new rational basis for studying different cARV or other anti-inflammatory interventions that can modify the risk of cardiovascular diseases and other complications that would contribute to improved prognoses for patients ${ }^{29}$.

Here, it was possible to note the importance in the balance of cytokines profile in HIV infection and the potential biomarker role of them to predict the rate of disease progression. Thus it could be suggested that cytokines, when are studied in isolate forms, does not shed light on the pathogenic or protective role of each one, neither could elucidate the clinical or immunological status of the individual. The biological effect of cytokines depends on their own interaction and, to be considered clear parameters in medical practice would be required study of a cytokines network expressed by the individual. 
However, it is need to evaluate the cost versus benefit of this proposal. For this, should considering the low serum levels of these cytokines and low sensitivity of the tests and the high costs involved in these dosages when used in routine clinical monitoring, as both in relation to the investment of the kits aquisition as technical training of a professional for correct analysis.

Many researchers support that the study of cytokines is exceeded, however this review showed that the abundance of studies on the subject does not justify the low of accurate responses, since the divergence of data does not allow a consensus on the real pro-viral and pro-host cytokines and their long-term relationship, in naïve or treated patients. More studies on the inflammatory and regulatory profiles are necessary to clarify the interaction between cytokine levels and the real clinical condition of the HIV infected, mainly whom with the prolonged use of CART.

\section{CONFLICT OF INTEREST}

The authors declare that there is no conflict of interest.

\section{ABSTRACT IN PORTUGUESE}

\section{Parâmetros imunovirológicos e citocinas na infecção pelo HIV}

Enquanto modernas terapias antirretrovirais (TARV) têm resultado em menores índices de morbidade e mortalidade e na melhora visível dos parâmetros clínicos e laboratoriais em infectados pelo HIV, sabe-se que seu uso em longo prazo contribui com aparecimento dos vários eventos não associados à aids como doenças cardiovasculares, cânceres e osteoporose, comorbidades as quais têm sido propostas como algumas das mais importantes que privam a maioria dos infectados pelo vírus a apresentarem prognóstico ainda melhor. Isso ocorre porque, mesmo com diminuição da inflamação e ativação imune após intervenção medicamentosa ao paciente, tais parâmetros continuam maiores que os apresentados por indivíduos saudáveis e o desequilíbrio dos perfis de citocinas também persiste. Por isso, avaliações de outros biomarcadores na prática clínica são necessárias para complementar os exames já realizados rotineiramente e permitir o monitoramento mais eficaz dos portadores do HIV. Esta revisão tem o intuito de investigar o papel das citocinas como potenciais marcadores, relacionando estudos sobre o comportamento de várias delas em diversas fases da infecção por HIV, na presença ou não de TARV.

Palavras-chaves: Citocinas. HIV/AIDS. Terapia antirretroviral. Fases clínicas da infecção.

\section{REFERENCES}

1. Ministério da Saúde. Secretaria de Vigilância em Saúde. Programa Nacional de DST e AIDS. Boletim epidemiológico - AIDS e DST. Ano IV. Brasília: Ministério da Sáude; 2007.

2. Vaishnav YN, Wong-Staal F. The Biochemistry of Aids. Annu Rev Biochem 1991; 60:577-630.

3. Mellors J, Rinaldo C, Gupta P. Prognosis in HIV-1 infection predicted by the quantity of virus in plasma. Science 1996; 272:1167-1170.

4. Coordenação Estadual de DST/AIDS [Internet]. Governo do Estado do Pará; [Cited 2011 April]. Available from: http://www.saude.pa.gov.br/.

5. Lifson AR, Hessol NA, Rutherford GW. Progression and clinical outcome of infection due to human immunodeficiency virus. Clin Infect Dis 1992;14:966-972.

6. Buchbinder SP, Katz MH, Hessol NA, O'Malley PM, Holmberg SD. Long-term HIV-1 infection without immunologic progression. AIDS 1994; 8:1123-1128.

7. Pantaleo G, Menzo S, Vaccarezza M, Graziosi C, Cohen OJ, Demarest JF, et al. Studies in subjects with long-term nonprogressive human immunodeficiency virus infection. N Engl J Med 1995; 332:209-216.
8. Okulicz JF, Marconi VC, Landrum ML, Wegner S, Weintrob A, Ganesan A, et al. Clinical outcomes of elite controllers, viremic controllers, and long-term nonprogressors in the US Department of Defense HIV Natural History Study. J Infect Dis 2009; 200:1714-1723.

9. Migueles SA, Laborico AC, Shupert WL, Sabbaghian MS, Rabin R, Hallahan CW, et al. HIV-specific CD8 T cell proliferation is coupled to perforin expression and is maintained in nonprogressors. Nat Immunol 2002; 3:1061-1068.

10. Paterson DL, Swindells S, Mohr J, Brester M, Vergis EN, Squier C, et al. Adherence to protease inhibitor therapy and outcomes in patients with HIV infection. Ann Intern Med 2000; 133:21-30.

11. Finzi D, Hermankova M, Pierson T, Carruth LM, Buck C, Chaisson RE, et al. Identification of a reservoir for HIV-1 in patients on highly active antiretroviral therapy. Science 1997; 278:1295-1300.

12. Mavigner M, Delobel $P$, Cazabat $M$, Dubois M, L'Faqihi-Olive FE, Raymond S, et al. HIV-1 residual viremia correlates with persistent T-cell activation in poor immunological responders to combination antiretroviral therapy. PLoS ONE 2009; 4:e7658.

13. Villacres MC, Kono N, Mack WJ, Nowicki MJ, Anastos K, Augenbraun M, et al. Interleukin 10 responses are associated with sustained CD4 T-cell counts in treated HIV infection. J Infect Dis 2012; 206:780-789.

14. Davey RT Jr, Bhat N, Yoder C, Chun TW, Metcalf JA, Dewar R, et al. HIV-1 and T cell dynamics after interruption of highly active antiretroviral therapy (HAART) in patients with a history of sustained viral suppression. Proc Natl Acad Sci USA 1999; 96:15109-15114.

15. Peçanha EP, Antunes OAC, Tanuri A. Estratégias farmacológicas para a terapia anti-AIDS. Química Nova 2002; 25:1108-1116.

16. Souza MVN, Almeida MV. Drogas anti-VIH: passado, presente e futuras perspectivas. Química Nova 2003; 26:366-373.

17. LaBonte J, Lebbos J, Kirkpatrick P. Efuvirtide. Nat Rev Drug Discov 2003; 2:345.

18. Ciccosanti F, Corazzani M, Soldani F, Matarrese P, Pagliarini V, ladevaia V, et al. Proteomic analysis identifies prohibitin down-regulation as a crucial event in the mitochondrial damage observed in HIV-infected patients. Antiv Ther 2010; 15:377-390.

19. Gutierrez M, Mateo GM, Vidal F, Domingo P. The toxicogenetics of antirretroviral therapy: the evil inside. Curr Med Chem 2011; 18:209-219.

20. Sousa AE. Citocinas e HIV - Revisão do tema através da análise a nível celular individualizado. II Congresso Virtual HIV/AIDS: Ontem, Hoje e Amanhã. [Cited 2011 June]. Available from: http://www.aidscongress.net/article.php?id_ comunicacao $=82 /$.

21. Pantaleo G. How immune-based interventions can change HIV therapy. Nat Med 1997; 3:483-486.

22. Imami N, Antonopoulos C, Hardy GA, Gazzard B, Gotch FM. Assessment of type 1 and type 2 cytokines in HIV type 1-infected individuals: impact of highly active antiretroviral therapy. AIDS Res Hum Retrov 1999; 15:1499-1508.

23. Gianella S, von Wyl V, Fischer M, Niederost B, Battegay M, Bernasconi E, et al. Effect of early antiretroviral therapy during primary HIV-1 infection on cell-associated HIV-1 DNA and plasma HIV-1 RNA. Antivir Ther 2011; 16:535-545.

24. Bowman MC, Archin NM, Margolis DM. Pharmaceutical approaches to eradication of persistent HIV infection. Expert Rev Mol Med 2009; 11:e6.

25. Fidler S, Ewings F, Porter K, Cooper D, Tambussi G, et al. A comparison of HIV viral rebound following ART cessation in primary and chronic HIV infection. Paper presented at: 17th Conference on Retroviruses and Opportunistic Infections; San Francisco, CA. February 16-19, 2010; [\#474] San Francisco, CA.

26. Pereira CCA, Machado CJ, Rodrigues RN. Perfis de causas múltiplas de morte relacionadas ao HIV/AIDS nos municípios de São Paulo e Santos, Brasil, 2001. Cad Saude Publica 2007; 23:645-655.

27. Cozzi-Lepri A, French MA, Baxter J, Okhuysen P, Plana M, Neuhaus J, et al. Resumption of HIV replication is associated with monocyte/ macrophage derived cytokine and chemokine changes: results from a large international clinical trial. AIDS 2011; 25:1207-1217.

28. Hunt PW, Martin JN, Sinclair E, Bredt B, Hagos E, Lampiris H, Deeks SG. T cell activation is associated with lower CD4+ $T$ cell gains in human immunodeficiency virus-infected patients with sustained viral suppression during antiretroviral therapy. J Infect Dis 2003; 187:1534-1543. 
29. Dubé MP, Sattler FR. Inflammation and complications of HIV disease. J Infect Dis 2010; 201:1783-1785.

30. Keating SM, Jacobs ES, Norris PJ. Soluble mediators of inflammation in HIV and their implications for therapeutics and vaccine development. Cytokine Growth F R 2012; 23: 193-206

31. Kedzierska K, Crowe SM. Cytokines and HIV-1: interactions and clinical implications. Antivir Chem Chemother 2001; 12: 133-150.

32. Osborn L, Kunkel S, Nabel GJ. Tumor necrosis factor alpha and interleukin 1 stimulate the human immunodeficiency virus enhancer by activation of the nuclear factor kappa B. Proc Natl Acad Sci USA 1989; 86:1336-1340.

33. Haissman JM, Vestergaard LS, Sembuche S, Erikstrup C, Mmbando B, Mtullu S, et al. Plasma Cytokine Levels in Tanzanian HIV-1-Infected Adults and the Effect of Antiretroviral Treatment. J Acquir Immune Defic Syndr 2009; 52:493-497.

34. Han X, Becker K, Degen HJ, Jablonowski H, Strohmeyer G. Synergistic stimulatory effects of tumour necrosis factor alpha and interferon gamma on replication of human immunodeficiency virus type 1and on apoptosis of HIV-1-infected host cells. Eur J Clin Invest 1996; 26:286-292.

35. Munoz-Fernandez MA, Navarro J, Garcia A, Punzón C, Fernández-Cruz E, Fresno M. Replication of human immunodeficiency virus-1 in primary human $\mathrm{T}$ cells is dependent on the autocrine secretion of tumor necrosis factor through the control of nuclear factor-kappa B activation. J Allergy Clin Immunol 1997; 100:838-845.

36. Roberts L, Passmore JS, Williamson C, Little F, Bebell LM, Mlisana K, et al. Plasma cytokine levels during acute HIV-1 infection predict HIV disease progression. AIDS 2010; 24:819-831.

37. Norris PJ, Pappalardo BL, Custer B, Spotts G, Hecht FM, Busch MP. Elevations in IL-10, TNF $\alpha$, and IFN- $\gamma$ from the earliest point of HIV Type 1 infection. AIDS Res Hum Retrov 2006; 22:757-762.

38. Rychert J, Strick D, Bazner S, Robinson J, Rosenberg E. Detection of HIV gp120 in plasma during early HIV infection is associated with increased proinflammatory and immunoregulatory cytokines. AIDS Res Hum Retrov 2010; 26:1139-1145.

39. Trinchieri G. Interleukin-12: a cytokine at the interface of inflammation and immunity. Adv Immunol 1998; 70:83-243.

40. Vassena L, Proschan M, Fauci AS, Lusso P. Interleukin 7 reduces the levels of spontaneous apoptosis in CD4+ and CD8+T cells from HIV-1-infected individuals. Proc Natl Acad Sci USA 2007; 104:2355-2360.

41. Stacey AR, Norris PJ, Qin L, Haygreen EA, Taylor E, Heitman J, et al. Induction of a striking systemic cytokine cascade prior to peak viremia in acute human immunodeficiency virus type 1 infection, in contrast to more modest and delayed responses in acute hepatitis B and C virus infections. J Virol 2009; 83: 3719-3733.

42. Eberly MD, Kader M, Hassan W, Rogers KA, Zhou J, Mueller YM, et al. Increased IL-15 production is associated with higher susceptibility of memory CD4 T cells to simian immunodeficiency virus during acute infection. J Immunol 2009; 182:14391448.

43. Wren L, Parsons MS, Isitman G, Center RJ, Kelleher AD, Stratov I, et al. Influence of cytokines on HIV-specific antibody-dependent cellular cytotoxicity activation profile of natural killer cells. PLoS ONE 2012; 7:e38580.

44. Clerici $\mathrm{M}$, Shearer GM. A TH-1/TH-2 switch is a critical step in etiology of HIV infection. Immunol Today 1993; 14:107-111.

45. Clerici M, Sarin A, Coffman RL, Wynn TA, Blatt SP, Hendrix CW, et al. Type 1/type 2 cytokine modulation of T-cell programmed cell death as a model for human immunodeficiency virus pathogenesis. Proc Natl Acad Sci USA 1994; 91:1181111815.

46. Estes JD, Wietgrefe S, Schacker T, Southern P, Beilman G, Reilly C, et al. Simian immunodeficiency virus-induced lymphatic tissue fibrosis is mediated by transforming growth factor beta 1-positive regulatory $\mathrm{T}$ cells and begins in early infection. J Infect Dis 2007; 195:551-561.

47. Huang J, Burke PS, Cung TD, Pereyra F, Toth I, Walker BD, et al. Leukocyte immunoglobulin-like receptors maintain unique antigen-presenting properties of circulating myeloid dendritic cells in HIV-1-infected elite controllers. J Virol 2010; 84:9463-9471

48. Redda AD, Dabitaob D, Breamb JH, Charvat B, Laeyendecker O, Kiwanuka N, et al. Microbial translocation, the innate cytokine response, and HIV-1 disease progression in Africa. PNAS 2009; 106:6718-6723.
49. Betts MR, Nason MC, West SM, De Rosa SC, Migueles SA, Abraham J, et al. HIV nonprogressors preferentially maintain highly functional HIV-specific CD8+T cells. Blood 2006; 107:4781-4789.

50. Li $Y$, Ling $W, X u H$, Wang $M$, Wu $C$. The activation and dynamics of cytokine expression by CD4+ T cells and AIDS progression in HIV-1-infected Chinese individuals. Microb Pathogenesis 2012; 53:189-197.

51. French MA, King MS, Tschampa JM, Silva BA, Landay AL. Serum immune activation markers are persistently increased in patients with HIV infection after 6 years of antiretroviral therapy despite suppression of viral replication and reconstitution of CD4+ T cells. J Infect Dis 2009; 200:1212-1215.

52. Nixon DE, Landay AL. Biomarkers of immune dysfunction in HIV. Curr Opin HIV AIDS 2010; 5:498-503.

53. Kamat A, Misra V, Cassol E, Ancuta P, Yan Z, Li C, et al. A plasma biomarker signature of immune activation in HIV patients on antiretroviral therapy. PLOS ONE 2012; 7:e30881.

54. Gay C, Dibben O, Anderson JA, Stacey A, Mayo AJ, Norris PJ, et al. Cross-sectional detection of acute HIV infection: timing of transmission, inflammation and antiretroviral therapy. PLoS ONE 2011; 6:e19617.

55. Neuhaus J, Jacobs DR Jr, Baker JV, Calmy A, Duprez D, La Rosa A, et al. Markers of inflammation, coagulation, and renal function are elevated in adults with HIV infection. J Infect Dis 2010; 201:1788-1795.

56. Regidor DL, Detels R, Breen EC, Widney DP, Jacobson LP, Palella F, et al. Effect of highly active antiretroviral therapy on biomarkers of B-lymphocyte activation and inflammation. AIDS 2011, 25:303-314.

57. Stylianou E, Aukrust P, Kvale D, Müller F, Frøland SS. IL-10 in HIV infection: increasing serum IL-10 levels with disease progression-down-regulatory effect of potent antiretroviral therapy. Clin Exp Immunol 1999; 116:115-120.

58. Sachdeva RK, Wanchu A, Bagga R, Malla N, Sharma M. Effect of non-nucleoside reverse transcriptase inhibitors on cytokine, chemokine, and immunoglobulin profiles in serum and genital secretions of HIV-infected women. J Interferon \& Cytokine Res 2010; 30:299-310.

59. Negredo E, Massanella M, Puig J, Pérez-Alvarez N, Gallego-Escuredo JM, Villarroya J, et al. Nadir CD4 T cell count as predictor and high CD4 T cell intrinsic apoptosis as final mechanism of poor CD4 T cell recovery in virologically suppressed HIV-infected patients: clinical implications. Clin Infect Dis 2010; 50:1300-1308.

60. Resino S, Belloan JM, Sanchez-Ramoa AS, Gurbindo D, Muñóz-Fernandez MA. Clinical relevance of cytokine production in HIV-1 infection in children on antiretroviral therapy. Scand J Immunol 2000; 52:634-640.

61. Moore KW, O' Garra A, de Waal Malefyt R, Vieira P, Mosmann TR. Interleukin-10. Annu Rev Immunol 1993; 11:165-190.

62. Del Prete G, De Carli M, Almerigogna F, Giudizi MG, Biagiotti R, Romagnani S. Human IL-10 is produced by both type 1 helper (Th1) and type 2 helper (Th2) T cell clones and inhibits their antigen-specific proliferation and cytokine production. J Immunol 1993; 150:353-360.

63. Barqasho B, Nowak P, Tjernlund A, Kinloch S, Goh LE, Lampe F, et al. Kinetics of plasma cytokines and chemokines during primary HIV-1 infection and after analytical treatment interruption. British HIV Association. HIV Med 2009; 10:94-102.

64. Appay V, Sauce D. Immune activation and inflammation in HIV-1 infection: causes and consequences. J Pathol 2008; 214:231-241.

65. Autran B, Carcelain G, Debre P. Immune reconstitution after highly active antiretroviral treatment of HIV infection. Adv Exp Med Biol 2001; 495:205-212.

66. Meira DA, Almeida RAMB, Barbosa NA, Souza LR, Olivo TET, Henriques RMS, et al. Assessment of cytokine values in serum by RT-PCR in HIV-1 infected individuals with and without highly active anti-retroviral therapy (HAART). J Venom Anim Toxins incl Trop Dis 2008; 14:685-702.

67. Orsilles MA, Pieri E, Cooke P, Caula C. IL-2 and IL-10 serum levels in HIV-1-infected patients with or without active antiretroviral therapy. APMIS 2006; 114:55-60.

68. Shearer GM, Clerici M. Protective immunity against HIV infection: has nature done the experiment for us? Immunol Today 1996; 17:21-24.

69. Wiercinska-Drapalo A, Jaroszewicz J, Flisiak R, Prokopowicz D. Plasma interleukin-18 is associated with viral load and disease progression in HIV-1-infected patients. Microbes Infect 2004; 6:1273-1277. 
70. Torre D, Pugliese A. Interleukin-18: a proinflammatory cytokine in HIV-1 infection. Curr HIV Res 2006; 4:423-430.

71. Kovacs JA, Lempicki RA, Sidorov IA, Adelsberger JW, Herpin B, Metcalf JA, et al. Identification of dynamically distinct subpopulations of T lymphocytes that are differentially affected by HIV. J Exp Med 2001; 194:1731-1741.

72. Brenchley JM, Price DA, Douek DC. HIV disease: fallout from a mucosal catastrophe? Nat Immunol 2006; 7:235-239.

73. Huang W, Na L, Fidel PL, Schwarzenberger P. Requirement of interleukin-17A for systemic anti-Candida albicans host defense in mice. J Infect Dis 2004; 190:624-631.

74. Ye P, Garvey PB, Zhang P, Nelson S, Bagby G, Summer WR, et al. Interleukin-17 and lung host defense against Klebsiella pneumoniae infection. Am J Respir Cell Mol Biol 2001; 25:335-340.

75. Amadi-Obi A, Yu CR, Liu X, Mahdi RM, Clarke GL, Nussenblatt RB, et al. TH17 cells contribute to uveitis and scleritis and are expanded by IL-2 and inhibited by IL-27/ STAT1. Nat Med 2007; 13:11-718.

76. Steinman L. A rush to judgment on Th17. J Exp Med 2008; 205:1517-1522.

77. Maek-A-Nantawat W, Buranapraditkun S, Klaewsongkram J, Ruxrungthum K. Increased interleukin-17 production both in helper T Cell subset Th17 and CD4negative T cells in human immunodeficiency virus infection. Viral Immunol 2007; 20:328.

78. Ferretti S, Bonneau O, Dubois GR, Jones CE, Trifilieff A. IL-17, produced by lymphocytes and neutrophils, is necessary for lipopolysaccharide-induced airway neutrophilia: IL-15 as a possible trigger. J Immunol 2003; 170:2106-2112.

79. Shin HC, Benbernou N, Esnault S, Guenounou M. Expression of IL-17 in human memory CD45RO_T lymphocytes and its regulation by protein kinase A pathway. Cytokine 1999; 11:257-266.

80. Sofi MH, Liu Z, Zhu L, Yu Q, Kaplan MH, Chang CH. Regulation of IL-17 expression by the developmental pathway of CD4 T cells in the thymus. Mol Immunol 2010; 47:1262-1268.

81. Rachitskaya AV, Hansen AM, Horai R, Li Z, Villasmil R, Luger D, et al. Cutting edge: NKT cells constitutively express IL-23 receptor and RORgammat and rapidly produce IL-17 upon receptor ligation in an IL-6-independent fashion. J Immunol 2008; 180:5167-5171.

82. Korn T, Bettelli E, Oukka M, Kuchroo VK. IL-17 and Th17 Cells. Annu Rev Immunol 2009; 27:485-517.

83. Yang L, Anderson DE, Baecher-Allan C, Hastings WD, Bettelli E, Oukka M, et al. IL-21 and TGF-beta are required for differentiation of human $T(H) 17$ cells. Nature 2008; 454:350-352.

84. Bettelli E, Korn T, Kuchroo VK. Th17: the third member of the effector T cell trilogy. Curr Opin Immunol 2007; 19:652-657.

85. Hou W, Kang HS, Kim BS. Th17 cells enhance viral persistence and inhibit T cell cytotoxicity in a model of chronic virus infection. J Exp Med 2009; 206: 313-328.

86. Korn T, Bettelli E, Gao W, Awasthi A, Jäger A, Strom TB, et al. IL-21 initiates an alternative pathway to induce proinflammatory $T(H) 17$ cells. Nature 2007; 448:484-487.

87. Barker BR, Parvani JG, Meyer D, Hey AS, Skak K, Letvin NL. IL-21 induces apoptosis of antigen-specific CD8+ T lymphocytes. J Immunol 2007; 179:3596-3603.

88. Hed AE, Khaitan A, Kozhaya L, Manel N, Daskalakis D, Borkowsky W, et al. Susceptibility of human Th17 cells to human immunodeficiency virus and their perturbation during infection. J Infect Dis 2010; 201:843-854.

89. Brenchley JM, Paiardini M, Knox KS, Asher Al, Cervasi B, Asher TE, et al. Differential Th17 CD4 T-cell depletion in pathogenic and nonpathogenic lentiviral infections. Blood 2008; 112:2826-2835.

90. Ciccone W, Thompson J, Greenwald J, Hodge J, Lee P, Yao M, et al. CD4 T cell populations, including Th17 and cycling subsets, are intact in the gut mucosa of
HIV-1 infected LTNP. $17^{\text {th }}$ Conference on Retroviruses and Opportunistic Infections. Abstract 373, 2010.

91. Cecchinato V, Trindade CJ, Laurence A, Heraud JM, Brenchley JM, Ferrari MG, et al. Altered balance between Th17 and Th1 cells at mucosal sites predicts AIDS progression in simian immunodeficiency virus-infected macaques. Mucosal Immunol 2008; 1: 279-288.

92. Salgado $\mathrm{M}$, Rallón $\mathrm{NI}$, Rodés $\mathrm{B}$, López $\mathrm{M}$, Soriano $\mathrm{V}$, Benito JM. Long-term nonprogressors display a greater number of Th17 cells than HIV-infected typical progressores. Clin Immunol 2011;139:110-114.

93. Favre D, Lederer S, Kanwar B, Ma ZM, Proll S, Kasakow Z, et al. Critical loss of the balance between Th17 and T regulatory cell populations in pathogenic SIV infection. Plos Phatogens 2009; 2:e1000295.

94. Macal M, Sankaran S, Chun TW, Reay E, Flamm J, Prindiville TJ, Dandekar S. Effective CD4+ Tcell restoration in gut-associated lymphoid tissue of HIV-infected patients is associated with enhanced Th17 cells and polyfunctional HIV-specific T-cell responses. Mucosal Immunol 2008; 1:475-488.

95. Kader M, Wang X, Piatak M, Lifson J, Roederer M, Veazey R, Mattapallil JJ. Alpha4(+) beta7(hi)CD4(+) memory T cells harbor most Th-17 cells and are preferentially infected during acute SIV infection. Mucosal Immunol 2009; 2:439-449.

96. MacDonald TT, Murch SH. Aetiology and pathogenesis of chronic inflammatory bowel disease. Baillieres Clin Gastroenterol 1994; 8:1-34.

97. Heise C, Miller CJ, Lackner A, Dandekar S. Primary acute simian immunodeficiency virus infection of intestinal lymphoid tissue is associated with gastrointestinal dysfunction. J Infect Dis 1994; 169:1116-1120.

98. Cummins AG, LaBrooy JT, Stanley DP, Rowland R, Shearman DJ. Quantitative histological study of enteropathy associated with HIV infection. Gut 1990;31:317-321.

99. Clayburgh DR, Shen L, Turner JR. A porous defense: the leaky epithelial barrier in intestinal disease. Lab Invest 2004; 84:282-291.

100. Nigam P, Kwa S, Velu V, Amara RR. Loss of IL-17-Producing CD8 T Cells during Late Chronic Stage of Pathogenic Simian Immunodeficiency Virus Infection. J Immunol 2011; 186:745-753.

101. Gori A, Tincati C, Rizzardini G, Torti C, Quirino T, Haarman M, et al. Early impairment of gut function and gut flora supporting a role for alteration of gastrointestinal mucosa in human immunodeficiency virus pathogenesis. J Clin Microbiol 2008; 46:757-758.

102. Brenchley JM, Price DA, Schacker TW, Asher TE, Silvestri G, Rao S, et al. Microbial translocation is a cause of systemic immune activation in chronic HIV infection. Nat Med 2006; 12: 1365-1371.

103. Li Q, Estes JD, Duan L, Jessurun J, Pambuccian S, Forster C, et al. Simian immunodeficiency virus-induced intestinal cell apoptosis is the underlying mechanism of the regenerative enteropathy of early infection. J Infect Dis 2008; 197:420-429.

104. Lawn SD, Butera ST, Folks TM. Contribution of immune activation to the pathogenesis and transmission of human immunodeficiency virus type 1 infection. Clin Microbiol 2001; 14:753-777.

105. Klatt NR, Brenchley JM. Th17 Cell Dynamics in HIV Infection. Curr Opin HIV AIDS 2010; 5:135-140.

106. Fonseca LC, Martins FL, Vieira RCPA, Pereira RMC, Ferreira AS, Raposo NRB. Evaluation of inadequate anti-retroviral treatment in patients with HIV/AIDS. Rev Soc Bras Med Trop 2012; 45:151-155.

107. Hunt PW. Th17, Gut, and HIV: Therapeutic implications. Curr Opin HIV AIDS 2010; 5:189-193.

108. Kuller LH, Tracy R, Belloso W, De Wit S, Drummond F, Lane HC, et al. Inflammatory and coagulation biomarkers and mortality in patients with HIV infection. PLoS Med 2008; 5:1496-1498.

109. Sandler NG, Wand H, Roque A, Law M, Nason MC, Nixon DE, et al. Plasma Levels of Soluble CD14 independently predict mortality in HIV infection. J Infect Dis Advance 2011; 203:780-790. 